\title{
Where is the Highest Rate of Children with Anemia in Peru? An Answer using Grey Systems
}

\author{
Alexi Delgado ${ }^{1}$ \\ Department of Engineering, Mining Engineering Section \\ Pontificia Universidad Católica del Perú \\ Lima, Peru
}

\author{
Nicolly Perez Ccancce ${ }^{2}$ \\ Systems Engineering Program \\ Universidad de Ciencias y Humanidades \\ Lima, Peru
}

\begin{abstract}
Anemia, or chronic malnutrition, in children under 5 is a social problem that affects the infant crucially in his or her growth and cognitive development. However, this problem presents itself in different ways in each department of Peru. Thus, in this work, the methodology of grey clustering, which is based on grey systems theory, was applied. The case study was conducted in the 25 departments of Peru, to analyze the departments most affected by chronic malnutrition in children under 5 years of age. The results of the study were that the departments of Cajamarca, Huancavelica, Loreto and Pasco have the highest rate of children with anemia; this may be due to the fact that these departments have greater poverty or negligence with respect to proper food handling. The results of this study could help local authorities such as the Ministry of Health to combat malnutrition, and also serve as a basis for future studies to evaluate the social impact of other conditions on health from a mathematical perspective.
\end{abstract}

\section{Keywords-Anemia; CTWF; grey systems; grey clustering}

\section{INTRODUCTION}

One of the public health problems that most afflicts the global population is anemia; which is not only the most frequent and most widespread, but also affects particularly the most vulnerable populations such as infants and women of reproductive age as stated by [1] according to [2]. Anemia according to [3] is defined as a decrease in hemoglobin concentration. It is a complex condition that occurs when there is a shortage of red blood cells in the body to adequately meet physiological needs [4]. In this regard, WHO stated that 528.7 million women and 273.2 million children under 5 years of age were anemic by 2011 worldwide [5]. This is alarming given that, in the case of preschool children, it affects their growth and destabilizes their nutrients [6]. However, specifically in the case of Peru, according to a technical report published by the Ministry of Health, [7] it is estimated that 6 out of 10 children between the ages of 6 and 12 months present anemia, a worrisome reality that requires greater monitoring.

For the present research, Grey clustering methodology, which is based on grey systems theory, was used. Initially developed by Deng in 1985 [8], it is a mathematical method clustering analysis [9], which is based on the application of Center-Point Triangular Whitenization Weight Functions (CTWF) [10], with the objective of classifying observation groups into particular categories [11]. This methodology was selected since it has been applied to different challenges, which show a high level of uncertainty or limited information [10], such as social impact assessment [12], crime management [10], security management [13], level of learning [8], among others. Therefore, it has a high degree of adaptability in the case study of this work.

Likewise, in order to achieve the most precise monitoring possible, data provided by the National Institute of Statistics and Informatics (INEI by its Spanish acronym) [14] will be used to facilitate the classification of a central point in the class interval [15].

The purpose of this study is to identify the departments that have the highest percentage of children under 5 years of age who have anemia in Peru, in order to identify the populations that have the greatest need for prevention programs by the Ministry of Health.

This paper is organized as follows, Section II is an explanation of the Grey Clustering method. Section III describes the application in the case study. This is followed by the results and discussion in Section IV. Finally, the conclusions are presented in Section V.

\section{Methodology}

The methodology to be used for the development of th1is research will be Grey Clustering; this is developed as follows: first, assume that there is a set of $\mathrm{m}$ objects, $\mathrm{n}$ criteria, $\mathrm{s}$ classes of grey and sample value $x_{i j}(i=1,2, \ldots, m ; j=$ $1,2, \ldots, n)$. Then, the steps of the Grey Clustering method can be described as below [16]:

Step 1: The intervals of the criteria are divided into $s$ grey classes, then the central points $\lambda_{1}, \lambda_{2}, \ldots$ and $\lambda_{s}$ are determined.

Step 2: Grey classes are distributed in two directions, adding the grey classes 0 and $(s+1)$ with their central points $\lambda_{0}$ and $\lambda_{s+1}$; as shown in Fig. 1 . 


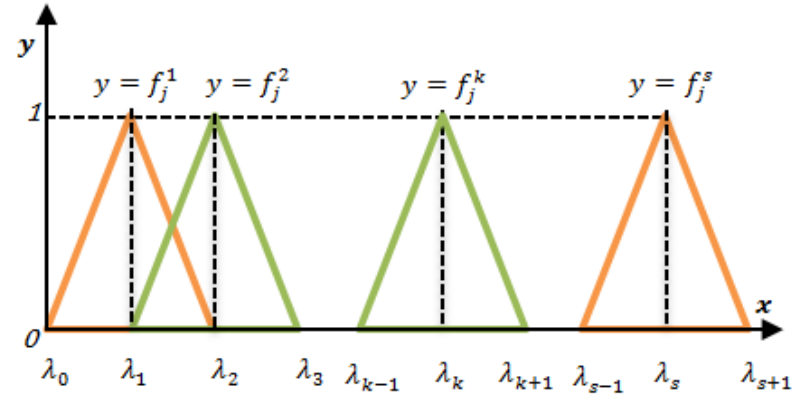

Fig. 1. Center-Point Triangular Whitenization Weight [17].

Step 3: The clustering coefficient, that indicates the weight of the criteria, for the group $i, i=1,2, \ldots, m$, in the grey class $k, k=1,2, \ldots, s$, is determined using (1).

$f_{j}^{k}\left(x_{i j}\right)=\left\{\begin{array}{c}0, x \notin\left[\lambda_{k-1} \lambda_{k+1}\right] \\ \frac{x-\lambda_{k-1}}{\lambda_{k}-\lambda_{k-1}}, x \in\left[\lambda_{k-1}, \lambda_{k}\right] \\ \frac{\lambda_{k+1}-x}{\lambda_{k+1}-\lambda_{k}}, x \in\left[\lambda_{k}, \lambda_{k+1} D\right]\end{array}\right.$

Step 4: If $\max _{1 \leq k \leq s}\left(f_{i}^{k}\right)=f_{i}^{k^{*}}$ it is decided that object $i$ belongs to grey class $k *$, the objects can be ordered according to the magnitudes of their coefficients [10].

\section{CASE STUDY}

For the application of the analysis, the data of children under 5 years old with chronic malnutrition rate (also known as anemia) was observed in the metrics of the twenty-five Peruvian departments. Fig. 2 shows the values given to each department for the present study.

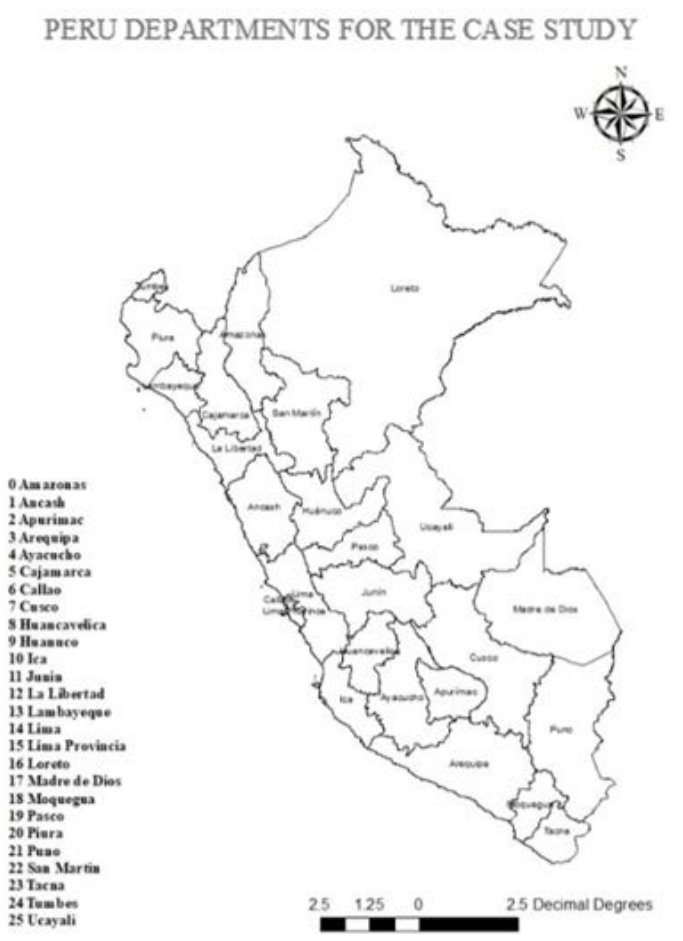

Fig. 2. Values given to the Peruvian Departments in the Current Research.

\section{A. Context Overview}

Currently, anemia in children under five years of age can be identified as a major risk since the growth and proper development of the infant is affected [18]. One approach to solving this problem could be to analyze the prevalence of children under five years of age with malnutrition in order to assess the management of this issue in each department. To conduct this research, data for 2017 was obtained from the website of the National Institute of Statistics and Information (INEI) [14]. The data obtained is presented in Table I.

TABLE I. CHILDREN UNDER 5 WITH ANEMIA BY DEPARTMENT

\begin{tabular}{|l|l|l|l|}
\hline Department & Children affected & Department & Children affected \\
\hline 0 & 17.1 & 13 & 10.5 \\
\hline 1 & 16.1 & 14 & 5.1 \\
\hline 2 & 20.9 & 15 & 9.6 \\
\hline 3 & 4.9 & 16 & 23.8 \\
\hline 4 & 20.0 & 17 & 7.3 \\
\hline 5 & 26.6 & 18 & 3.4 \\
\hline 6 & 5.2 & 19 & 22.8 \\
\hline 7 & 13.4 & 20 & 15.9 \\
\hline 8 & 31.2 & 21 & 16.1 \\
\hline 9 & 19.6 & 22 & 12.1 \\
\hline 10 & 8.3 & 23 & 3.2 \\
\hline 11 & 17.3 & 24 & 8.2 \\
\hline 12 & 15.6 & 25 & 19.4 \\
\hline
\end{tabular}

\section{B. Assessment Criteria}

Calculations based on Grey Clustering method are preceded as follows:

Step 1: The center points $\lambda_{1}, \lambda_{2}, \lambda_{3}, \lambda_{4}$, and $\lambda_{5}$, of five grey classes were determined as shown in Table II.

Step 2: To the four grey classes determined above, classes $s_{0}$ and $s_{5}$ were added; as shown in Table III and Fig. 3.

Step 3: The values presented in Table III were replaced in (1), to obtain the CTWF for the four grey classes. The results are shown in (2)-(5):

$$
\begin{aligned}
& f_{j}^{1}(x)=\left\{\begin{array}{c}
0, x \notin[0,13.7] \\
\frac{x-0}{6.7}, x \in[0,6.7] \\
\frac{13.7-x}{7}, X \in[6.7,13.7]
\end{array}\right. \\
& f_{j}^{2}(x)=\left\{\begin{array}{c}
0, x \notin[6.7,20.7] \\
\frac{x-6.7}{7}, x \in[6.7,13.7] \\
\frac{20.7-x}{7}, X \in[13.7,20.7]
\end{array}\right. \\
& f_{j}^{3}(x)=\left\{\begin{array}{c}
0, x \notin[13.7,27.7] \\
\frac{x-13.7}{7}, x \in[13.7,20.7] \\
\frac{27.7-x}{7}, X \in[20.7,27.7]
\end{array}\right.
\end{aligned}
$$


$f_{j}^{4}(x)=\left\{\begin{array}{c}0, x \notin[20.7,34.4] \\ \frac{x-20.7}{7}, x \in[20.7,27.7] \\ \frac{34.4-x}{6.7}, X \in[27.7,34.4]\end{array}\right.$

Following this, the values in Table I were replaced in (2)(5). The results are shown in Table IV.

Step 4: Finally, the requirement $\max _{1 \leq \mathrm{k} \leq \mathrm{s}}\left(\mathrm{f}_{\mathrm{i}}^{\mathrm{k}}\right)=\mathrm{f}_{\mathrm{i}}^{\mathrm{k}^{*}}$ was applied; thus, it was decided that $i$ belongs to the grey class $k *$, for each department. The results are shown in Table V.

TABLE II. CASE STUDY CLASSES

\begin{tabular}{|l|l|l|l|}
\hline $\begin{array}{l}\text { Very low class } \\
\left(\lambda_{1}\right)\end{array}$ & Low class $\left(\lambda_{2}\right)$ & $\begin{array}{l}\text { Medium class } \\
\left(\lambda_{3}\right)\end{array}$ & High class $\left(\lambda_{4}\right)$ \\
\hline$[3.2-10.2\rangle$ & {$[10.2-17.2\rangle$} & {$[17.2-24.2\rangle$} & {$[24.2-31.2\rangle$} \\
\hline 6.7 & 13.7 & 20.7 & 27.7 \\
\hline
\end{tabular}

TABLE III. CENTRAL Points of THE EXTENDED GREy Classes

Central points of the extended grey classes

\begin{tabular}{|l|l|l|l|l|l|}
\hline$\lambda 0$ & $\lambda 1$ & $\lambda 2$ & $\lambda 3$ & $\lambda 4$ & $\lambda 5$ \\
\hline 0 & 6.7 & 13.7 & 20.7 & 27.7 & 34.4 \\
\hline
\end{tabular}

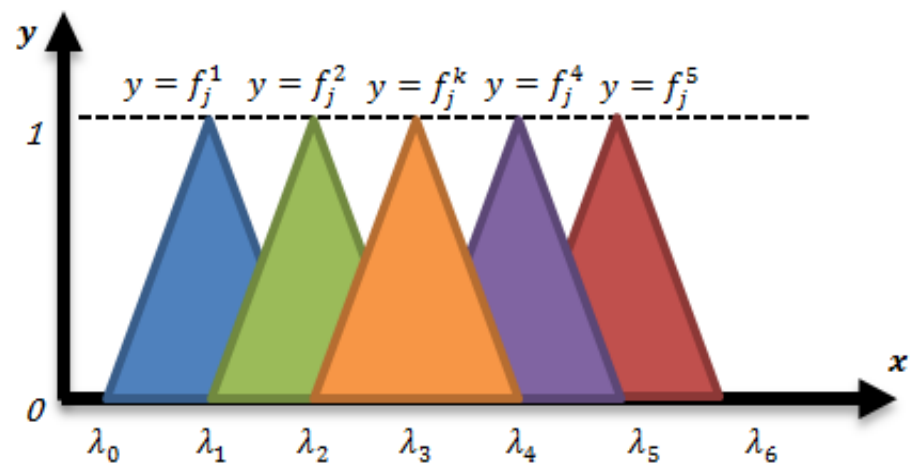

Fig. 3. CTWF for the Case Study.
TABLE IV. CTWF VALUE FOR EACH PERUVIAN DEPARTMENT

\begin{tabular}{|c|c|c|c|c|}
\hline Departments & 0 & 1 & 2 & 3 \\
\hline$f_{j}^{1}(x)$ & 0.00 & 0.00 & 0.0 & 0.73 \\
\hline $\mathrm{f}_{\mathrm{j}}^{2}(\mathrm{x})$ & 0.51 & 0.65 & 0.00 & 0.00 \\
\hline$f_{j}^{3}(x)$ & 0.48 & 0.34 & 0.97 & 0.00 \\
\hline $\mathrm{f}_{j}^{4}(\mathrm{x})$ & 0.0 & 0.00 & 0.02 & 0.00 \\
\hline Departments & 4 & 5 & 6 & 7 \\
\hline$f_{j}^{1}(x)$ & 0.00 & 0.00 & 0.77 & 0.04 \\
\hline $\mathrm{f}_{\mathrm{j}}^{2}(\mathrm{x})$ & 0.1 & 0.00 & 0.00 & 0.95 \\
\hline $\mathrm{f}_{\mathrm{j}}^{3}(\mathrm{x})$ & 0.9 & 0.15 & 0.00 & 0.00 \\
\hline $\mathrm{f}_{\mathrm{j}}^{4}(\mathrm{x})$ & 0.00 & 0.84 & 0.00 & 0.00 \\
\hline Departments & 8 & 9 & 10 & 11 \\
\hline $\mathrm{f}_{\mathrm{j}}^{1}(\mathrm{x})$ & 0.00 & 0.00 & 0.77 & 0.00 \\
\hline$f_{j}^{2}(x)$ & 0.00 & 0.15 & 0.22 & 0.78 \\
\hline $\mathrm{f}_{\mathrm{j}}^{3}(\mathrm{x})$ & 0.00 & 0.84 & 0.00 & 0.51 \\
\hline $\mathrm{f}_{\mathrm{j}}^{4}(\mathrm{x})$ & 0.47 & 0.00 & 0.00 & 0.00 \\
\hline Departments & 12 & 13 & 14 & 15 \\
\hline$f_{j}^{1}(x)$ & 0.00 & 0.46 & 0.76 & 0.59 \\
\hline $\mathrm{f}_{\mathrm{j}}^{2}(\mathrm{x})$ & 0.73 & 0.54 & 0.00 & 0.41 \\
\hline $\mathrm{f}_{\mathrm{j}}^{3}(\mathrm{x})$ & 0.27 & 0.00 & 0.00 & 0.00 \\
\hline $\mathrm{f}_{\mathrm{j}}^{4}(\mathrm{x})$ & 0.00 & 0.00 & 0.00 & 0.00 \\
\hline Departments & 16 & 17 & 18 & 19 \\
\hline$f_{j}^{1}(x)$ & 0.00 & 0.91 & 0.50 & 0.00 \\
\hline $\mathrm{f}_{\mathrm{j}}^{2}(\mathrm{x})$ & 0.56 & 0.09 & 0.00 & 0.00 \\
\hline $\mathrm{f}_{\mathrm{j}}^{3}(\mathrm{x})$ & 0.44 & 0.00 & 0.00 & 0.70 \\
\hline $\mathrm{f}_{\mathrm{j}}^{4}(\mathrm{x})$ & 0.00 & 0.00 & 0.00 & 0.30 \\
\hline Departments & 20 & 21 & 22 & 23 \\
\hline$f_{j}^{1}(x)$ & 0.00 & 0.00 & 0.22 & 0.47 \\
\hline $\mathrm{f}_{\mathrm{j}}^{2}(\mathrm{x})$ & 0.69 & 0.66 & 0.77 & 0.00 \\
\hline$f_{j}^{3}(x)$ & 0.31 & 0.34 & 0.00 & 0.00 \\
\hline $\mathrm{f}_{\mathrm{j}}^{4}(\mathrm{x})$ & 0.00 & 0.00 & 0.00 & 0.00 \\
\hline Departments & 24 & 25 & & \\
\hline$f_{j}^{1}(x)$ & 0.79 & 0.00 & & \\
\hline $\mathrm{f}_{\mathrm{j}}^{2}(\mathrm{x})$ & 0.21 & 0.19 & & \\
\hline $\mathrm{f}_{\mathrm{j}}^{3}(\mathrm{x})$ & 0.00 & 0.81 & & \\
\hline $\mathrm{f}_{\mathrm{j}}^{4}(\mathrm{x})$ & 0.00 & 0.00 & & \\
\hline
\end{tabular}

TABLE V. FinAL VALUES FOR EACH DEPARTMENT

\begin{tabular}{|c|c|c|c|c|c|c|}
\hline Department 0 & Department 1 & Department 2 & Department 3 & Department 4 & Department 5 & Department 6 \\
\hline $\begin{array}{l}0.51 \\
\text { Medium class }\end{array}$ & $\begin{array}{l}0.65 \\
\text { Medium class }\end{array}$ & $\begin{array}{l}0.97 \\
\text { Medium class }\end{array}$ & $\begin{array}{l}0.73 \\
\text { Medium class }\end{array}$ & $\begin{array}{l}0.9 \\
\text { Very low class }\end{array}$ & $\begin{array}{l}0.84 \\
\text { Medium class }\end{array}$ & $\begin{array}{l}0.77 \\
\text { High class }\end{array}$ \\
\hline Department 7 & Department 8 & Department 9 & Department 10 & Department 11 & Department 12 & Department 13 \\
\hline $\begin{array}{l}0.95 \\
\text { Low class }\end{array}$ & $\begin{array}{l}0.47 \\
\text { High class }\end{array}$ & $\begin{array}{l}0.84 \\
\text { Medium class }\end{array}$ & $\begin{array}{l}0.77 \\
\text { Low class }\end{array}$ & $\begin{array}{l}0.78 \\
\text { Medium class }\end{array}$ & $\begin{array}{l}0.73 \\
\text { Medium class }\end{array}$ & $\begin{array}{l}0.54 \\
\text { Low class }\end{array}$ \\
\hline Department 14 & Department 15 & Department 16 & Department 17 & Department 18 & Department 19 & Department 20 \\
\hline $\begin{array}{l}0.76 \\
\text { Very low class }\end{array}$ & $\begin{array}{l}0.59 \\
\text { Low class }\end{array}$ & $\begin{array}{l}0.56 \\
\text { High class }\end{array}$ & $\begin{array}{l}0.91 \\
\text { Very low class }\end{array}$ & $\begin{array}{l}0.50 \\
\text { Very low class }\end{array}$ & $\begin{array}{l}0.70 \\
\text { High class }\end{array}$ & $\begin{array}{l}0.6 \\
\text { Medium class }\end{array}$ \\
\hline Department 21 & Department 22 & Department 23 & Department 24 & Department 25 & & \\
\hline \multirow{2}{*}{$\begin{array}{l}0.66 \\
\text { Medium class }\end{array}$} & \multirow{2}{*}{$\begin{array}{l}0.77 \\
\text { Low class }\end{array}$} & \multirow{2}{*}{$\begin{array}{l}0.47 \\
\text { Very low class }\end{array}$} & \multirow{2}{*}{$\begin{array}{l}0.79 \\
\text { Low class }\end{array}$} & \multirow{2}{*}{$\begin{array}{l}0.81 \\
\text { Medium class }\end{array}$} & & \\
\hline & & & & & & \\
\hline
\end{tabular}




\section{RESUlTS AND DISCUSSION}

\section{A. Results on the Case Study}

Fig. 4 was constructed from Table V. The result is shown below according to the levels of anemia obtained according to the Grey clustering methodology.

As shown in Fig. 4, the province of Huancavelica shows a high rate of children suffering from anemia at national level, followed by Cajamarca, Loreto and Pasco. This may be due to the fact that, as mentioned by the Peruvian Ministry of Health (MINSA in Spanish), the main factors that contribute to the existence of malnutrition in children are: a bad nutritional combination, poor hygiene in food preparation and avoiding healthy eating. Factors that are present in the department of Huancavelica; therefore, this entity seeks to implement collective activities to raise awareness among the population [7].

Another possible cause of anemia (or chronic malnutrition) to be considered is the lack of education and economic deprivation of mothers, which affects the nutrition of their children, since they acquire their knowledge and life skills through informal education [19].

On the other hand, provinces such as Arequipa, Madre de Dios, Moquegua, Lima and Tacna have the lowest levels of anemia in children. This may be due to the prevention of anemia in these provinces, as is the case in the department of Arequipa, where a growth and development monitoring program (CRED) organized by the Peruvian Ministry of Health has been implemented [4].

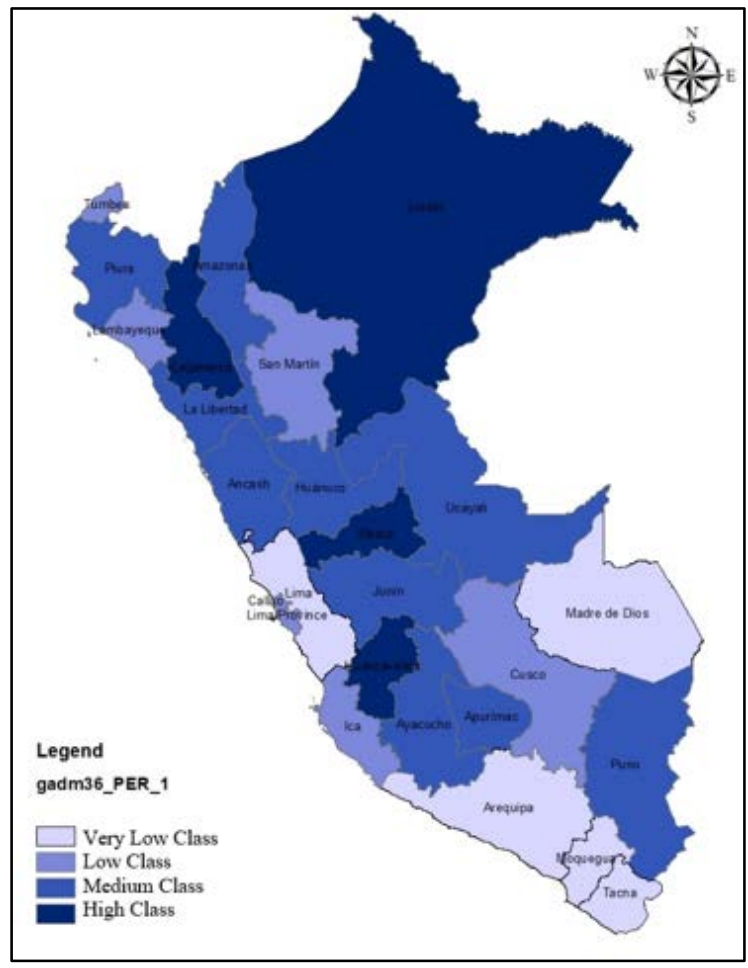

Fig. 4. Anemia Level in Children by Department.

\section{B. Discussion on the Methodology}

The Grey clustering method has helped to classify the data within levels optimally, based on previously collected data. The methodology has also proven to have advantages over other methods, such as Delphi [20], or the analytical hierarchy process (AHP) [21]; since the methods outlined do not consider uncertainty within the analysis [13]. Which is an important benefit, especially when dealing with social aspects.

\section{CONCLUSIONS}

The results obtained for the case study on the prevalence of anemia in children under 5 years of age are of interest, since it has been possible to identify the departments with the highest rate of the condition (Huancavelica, Loreto, Pasco and Cajamarca). This will be useful for decision-making by departmental authorities in Peru, such as MINSA and/or the central government, since it will allow them to concentrate their efforts on the inclusion of healthy food and greater hygiene programs in order to combat the current situation.

In addition, it has been demonstrated that the Grey Clustering method is an approach with a great capacity that allows us to apply it to social problems that present a high level of insecurity, given that this methodology allows us to analyze uncertainty.

Finally, in future research, this method could be applied to problems of social topics, such as the mathematical analysis of various diseases as diabetes, obesity, etc. as the social problem has been performed in the present research.

\section{REFERENCES}

[1] J. L. Miller, "Iron deficiency anemia: A common and curable disease," Cold Spring Harb. Perspect. Med., vol. 3, no. 7, Jul. 2013. DOI: 10.1101/cshperspect.a011866.

[2] N. Zavaleta and L. Astete-Robilliard, "Effect of anemia on child development: Long-term consequences," Rev. Peru. Med. Exp. Salud Publica, vol. 34, no. 4, pp. 716-722, Oct. 2017. DOI: dx.doi.org/10. 17843/rpmesp.2017.344.3251.

[3] Hospital Provincial de Castro, “Clinical Practice Guidelines: Prevention, Diagnosis and Treatment of Iron Deficiency Anemia in Children and Adults - Guía de Práctica Clínica: Prevención, Diagnóstico y Tratamiento de la Anemia por Deficiencia de Hierro en Niños y Adultos,” Cons. Salubr. Gen., pp. 1-57, 2009.

[4] C. Sotomayor-Beltran and G. Z. Segura, "A spatial assessment of anemia among Peruvian children aged 6 months to 5 years between 2016 and 2017," Congr. Argentino Ciencias la Inform. y Desarro. Investig. CACIDI 2018, pp. 1-5, 2018. DOI: https://doi.org/10.1109/ CACIDI.2018.8584359.

[5] OPS and OMS, "Iron deficiency anemia: Research for efficient and viable solutions - Anemia ferropénica: Investigación para soluciones eficientes y viables."

[6] J. A. M. M. Torres Lagrava, "Nutritional Chispitas and its administration to children from months to less than 2 years old Municipality of Icla Chuquisaca 2015 - Chispitas Nutricionales y su administración a niños de meses a menores de 2 años Municipio de Icla Chuquisaca 2015.”

[7] Ministerio de Salud del Perú, "National Plan for the Reduction and Control of Maternal and Child Anaemia and Chronic Malnutrition in Peru: 2017 - 2021 - Plan Nacional para la REDUCCIÓN Y CONTROL DE LA ANEMIA Materno Infantil y la Desnutrición Crónica Infantil en el Perú: 2017 - 2021,” Lima, 2017.

[8] A. Delgado, "Why do any secondary students prefer the mathematics? A response using grey systems,” Proc. 2017 Int. Symp. Eng. Accreditation, ICACIT 2017, pp. 1-4, 2018. DOI: https://doi.org/10.1109/ICACIT. 2017.8358082. 
[9] Y. Li, Y. Niu, W. Wang, and B. Li, "Grey-incidence clustering decisionmaking method with three-parameter interval grey number based on regret theory," in 2017 IEEE International Conference on Grey Systems and Intelligent Services, GSIS 2017, 2017, pp. 211-218. DOI: https://doi.org/10.1109/GSIS.2017.8077706.

[10] A. Delgado, P. Montellanos, and J. Llave, "Air quality level assessment in Lima city using the grey clustering method," in IEEE ICA-ACCA 2018 - IEEE International Conference on Automation/23rd Congress of the Chilean Association of Automatic Control: Towards an Industry 4.0 - Proceedings, 2019, 8609699.

[11] S. Liu and Y. Yang, "Explanation of terms of grey clustering evaluation models,” Grey Syst. Theory Appl., vol. 7, no. 1, pp. 129-135, Feb. 2017. DOI: https://doi.org/ 10.1108/GS-11-2016-0046.

[12] A. Delgado and I. Romero, "Applying the Grey Systems Theory to Assess Social Impact from an Energy Project,” Proc. 2018 IEEE 25th Int. Conf. Electron. Electr. Eng. Comput. INTERCON 2018, no. 2, pp. 1-4, 2018. DOI: https://doi.org/10.1109/INTERCON.2018.8526372.

[13] C. Li, K. Chen, and X. Xiang, "An integrated framework for effective safety management evaluation: Application of an improved grey clustering measurement," Expert Syst. Appl., vol. 42, no. 13, pp. 55415553, 2015. DOI: https://doi.org/10.1016/j.eswa.2015.02.053.

[14] INEI, "PERU Instituto Nacional de Estadística e Informática INEI." [Online]. Available: https://www.inei.gob.pe/estadisticas/indicetematico/sociales/. [Accessed: 22-Oct-2019].
[15] S. Liu and Y. Lin, "Interval Analysis and Grey Systems Theory," in Springer Science \& Business Media, 2010.

[16] M. Sacasqui, J. Luyo, and A. Delgado, “A Unified Index for Power Quality Assessment in Distributed Generation Systems Using Grey Clustering and Entropy Weight,” 2018 IEEE ANDESCON, ANDESCON 2018 - Conference Proceedings, 2018, 8564631.

[17] S. Liu and Y. Lin, Grey Systems Theory and Applications, vol. 68. Springer Berlin Heidelberg, 2011.

[18] Ministerio de Salud del Peru (MINSA), "Technical health standard for monitoring the growth and development of children under five - Norma tecnica de salud para el control del crecimiento y desarrollo de la niña y el niño menor de cinco años.,” Bibl. Cent. del Minist. Salud, p. 149, 2011.

[19] H. B. Urke, T. Bull, and M. B. Mittelmark, "Socioeconomic status and chronic child malnutrition: Wealth and maternal education matter more in the Peruvian Andes than nationally,” Nutr. Res., vol. 31, no. 10, pp. 741-747, 2011. https://doi.org/10.1016/j.nutres.2011.09.007.

[20] M. R.-álvarez M. Torrado-fonseca, "Delphi method - El método Delphi,” REIRE. Rev. d’Innovación i Recer. en Educ., vol. 9, no. 9 (1), pp. 0-2, 2016. https://doi.org/10.1344/reire2016.9.1916/.

[21] A. Priyadi, M. H. P, and M. Pujiantara, "Wind farm site selection base on fuzzy analytic hierarchy process method; Case study area Nganjuk," no. Mcdm, pp. 545-550, 2016. https://doi.org/10.1109/ISITIA.2016. 7828718. 